\title{
Forecast the End of the Anshorut Daulah (JAD) in Indonesia
}

\author{
Achmad Zainal Huda ${ }^{1}$, Muhamad Syauqillah ${ }^{2}$ \\ \{achmad.zaihud@gmail.com¹, muhamadsyauqillah@ui.ac.id² \\ ${ }^{1,2}$ Terrorism Studies, School of Strategic and Global Studies, Universitas Indonesia, \\ Jakarta, Indonesia
}

\begin{abstract}
The JAD was founded by Aman Abdurrahman while in the Nusakambangan Lapas was declared as a follower of ISIS. The growth of JAD is indeed metamorphosis from the previous group of JI, JAT, JAS and finally JAD after the emergence of ISIS in the Middle East. In recent years, terrorism researchers have begun to pay greater attention to the question of how group terrorism subsides or ends. This research focuses on how the Jamaah Anshorud Daulah (JAD) movement using a qualitative method with a case-study approach. This study shows that JAD movement will end difficultly. One of the necessary reason is that JAD movement moving with cell systems and lone-wolf attacks and the power of takfiri ideology held by JAD, like other terrorist groups becomes an 'obstacle' to kill JAD. So that, the government should have a great strategy to end the JAD movement.
\end{abstract}

Keywords: Forecasting, ISIS, Jamaah Anshorud Daulah (JAD), radical-terrorist group.

\section{Introduction}

Terrorism acts that shake the homeland continue to occur. Cases of prisoner terrorism rebellion at Mako Brimob has not yet been completed, a suicide bomb exploded in Surabaya. In Surabaya, the explosion of bombs did not only occur in three churches, even in the night the bomb exploded again in a condominium. In the worse, the bomb on the condominium involved a family, a married couple; one of his children died, and 3 other family members suffered injuries. The bomb exploded again at the Surabaya Police Officer with one family as actors. The other days, suicide bomb cases that include children occurred again in Sibolga, North Sumatra.

Terrorism acts in the world and Indonesia after 2014 has been associated with the ISIS group. After the ISIS group managed to seize several areas in Iraq and Syria, many Indonesian citizens pledged allegiance Amir (Caliph) ISIS; Abu Bakar Al-Baghdadi. Many Indonesian citizens depart for areas controlled by ISIS. Suicide bombers in 3 churches in Surabaya are one of the families who have returned from Syria. Besides, the main perpetrator of terror in 3 churches Surabaya is the chairman of the Congregation Ansharut Daulah (JAD) Surabaya area.

This article will explain the declining predictions or expiration of the JAD terrorist group in Indonesia, as well as the reason why the JAD group persists and continues to act until the Lone Wolf Terrorism, although some cases do not Relate to JAD. During this time the question of how the decline of terrorist groups was not carefully studied, and the existing research barely touched the realm. The previous studies "how terrorism ends: a comparative conflicted analysis of Northern Ireland, the Basque Country and Corsica" conclude that ending of terrorist campaigns are resulted by combination of coercion, mediation and, in the three cases but 
mediation and reform were dependent on the use of coercive measures targeted directly at the groups. $^{1}$

The same case which analyzed by Zulaika \& Murua with title "how terrorism end and does not end: the Basque case" showed that the end of terrorism movements not only the resulted by police repression and military defeat, or having succeeded in achieving the intended goals, but also when (a) prompted by failure, their political base compels them to cease the violence; (b) thus they deny the State its grip on the discourse of terrorism; (c) "a revolution in thought and politics" makes them take unilateral positions irrespective of their antagonist's reactions; (d) allow for mediating "third parties" as witnesses to the definitive disarmament and (e) define the "ending" from the perspective of their political base and the international community. ${ }^{2}$ Meanwhile, the same study has never been done in Indonesia. In the context of JAD in Indonesia, the security forces only focus on the arrest of individuals as well as the JAD network as the main objective of the campaign against JAD. Concentrating on the root causes of terrorism and urged policies that can change public support against JAD can lower the JAD movement.

JAD movement in Indonesia to this day starts from the congregation Islamiyah (JI) that affiliate to Al Qaeda. Later JI was metamorphosed (although there is still a group of JI until now) as another group of terrorism, such as the worshippers Ansharut Tauhid (JAT) and then became JAD who spoke to ISIS. Although continuing to make a massive movement, writers will try to predict the fall of JAD in Indonesia. Because it is affiliated with ISIS, the fall of JAD can relate to the fall of ISIS. However, it could be that JAD still survives even though ISIS has lost in Syria/Iraq.

\section{Literature Review}

\subsection{From Jamaah Islamiyah (JI) to Ansharut Daulah Jamaat (JAD)}

Cases of terrorism that occurred in Indonesia and the world before the emergence of ISIS, many associated with Al-Qaeda and Jemaah Islamiyah (JI). There seems to be a change in the links between Indonesian terrorists from Al-Qaeda to ISIS and from JI to JAD. JAD is identified as affiliated with ISIS, while JI is Al-Qaeda's global terrorism network. JI terrorist groups are trained in various fields, from Afghanistan, Thailand, Malaysia, and the Philippines. On a global scale, there are differences between Al-Qaeda and ISIS which also influence the pattern of attacks carried out by JI and JAD. The dispute between ISIS and Al Qaeda is more than a struggle for power in the jihadist movement. The two organizations differ in determining the main enemy, strategy, tactics, and other fundamental problems.

The differences above influence the character of JI and JAD in Indonesia. Al-Qaeda's combat experience on diverse battlefields makes the JI terror actions not only more precise but also has extremely high destructive power. The Bali I and II Bomb attacks by JI were more explosive than the terror in Surabaya that used a pipe bomb. The Bali Bombing I, for example, weighed 6 tons and killed 202 people. The attacks carried out by JI were more deadly than those

${ }^{1}$ Carl Peter Turner, "How terrorism ends: a comparative conflict analysis of Northern Ireland, the Basque Country, and Corsica," (Ph.D Thesis, University of Hull, 2015).

${ }^{2}$ Joseba Zulaika \& Imanol Murua, "How terrorism ends - and does not end: the Basque case, " Critical Studies on Terrorism, 10:2, 2017. 
carried out by JAD. JAD is originally prohibited in Indonesia. For the sustainability of the organization, the organization tries to cover formally, but clandestinely it will still exist with remain high treat. JAD has a recruitment and plot model through cyberspace as well as pushing lone wolf and migrating to conflict abroad (including Southern Philippines and Khorazan Afghanistan).

However, after the destruction of most of Al-Qaeda's power by the US on a worldwide scale, and the reducing of JI action after the death of JI leaders such as Doctor Azhari and Nurdin M Top, JI's dominant position began to be replaced by JAD. This change is a reflection of changes at the worldwide level. JAD is a group whose formation was initiated at the end of 2014 in Kembangkuning Nusakambangan Lapas, Cilacap, Central Java. Aman Abdurrahman hopes JAD will be able to become an umbrella organization for ISIS support groups in Indonesia. JAD dominates the media coverage of terrorism in Indonesia. Although JAD now dominates the reporting of terrorist attacks, the lines of command or independent cell systems for attack initiatives need to be explored further.

Besides the changes that occurred in terrorism in 2010-2018 were changed in terror targets. The targets of terrorism are no longer Western symbols, but rather civil society, security forces, especially the police. The emergence of JAD does not change this phenomenon. JAD continues to target civil society and the police. Terror in Indonesia has reached a new phase. When building an organization with a strong military wing is already impossible. We know that the last paramilitary camp was in Jantho which had not yet been able to operate because it was quickly dismantled by the authorities in 2010. The militants are now moving independently and sporadically without any centralized chain of command.

From this, it appears prominent that there has been a change in the orientation of terrorism in Indonesia. The change in question is the abandonment of the Tanzhim or organization as a vehicle for the movement by starting the emergence of individual terrorism or Lone Wolf Terrorism and the spread of takfiri ideals driven by supporters of ISIS in Indonesia. As a result, acts of terrorism that occurred in Indonesia in the period 2010-2015 experienced changes to be sporadic, unclear, and different from the previous period in terms of the number and intensity of terror attacks, modus operandi, targets of terrorist acts, and the actors involved. The emergence of the names Aman Abdurrahman and JAD after the Sarinah and Surabaya bombings could slightly strengthen the Lone Wolf Terrorism. However, their appearance still does not change the change in the pattern of attacks that are sporadic, but less deadly than 2000-2009. This paper will explain about forecasting, how JAD terrorist groups decline or end. Why do they still survive and continue to take action independently?

\subsection{Cycles, Stages, Waves, and Phases}

Another approach to understanding the life span of a terrorist movement is to look for identifiable cycles. Terrorism trends during late 20th century show that transnational terrorist attacks go on periods, with peaks approximately every two years. Other experts have focused on the existence of stages of development through which all terrorist groups evolve, especially the psychological stage of increasing alienation or moral release for groups, individuals, or both. Leonard Weinberg and Louise Richardson have explored the application of conflict theory frameworks (including the stages of emergence, escalation, and de-escalation) to the life cycle of terrorist groups. They conclude that this framework is useful in examining terrorist groups operating in Western Europe at the end of the 20th century. There are still other analysts who suggest specific types of groups can have their stages of development. Ehud Sprinzak, for example, argues that the right-wing group shows a unique cycle pattern. Encouraged by 
particular complaints against their particular groups, members direct their hostility towards segments of the "enemy" of the population determined by who they are concerning race, religion, sexual preference, ethnicity. To the extent that the government defends the target population, the first is also a "legitimate" target. ${ }^{3}$

Rapoport argues that during modern history, a wave of international terrorist activity remaining around one generation, around forty years. These waves are characterized by expansion and contraction which have an international character, with similar activities in several countries driven by shared ideologies. The necessary factors for the Rapoport wave are transformation in communication or transportation patterns, and new doctrines or cultures. Although the waves consist of terrorist organizations and their activities, they do not need to exist simultaneously. According to Rapoport again, because most individual organizations have a short life span, they often disappear before a giant wave loses power. However, the current wave of jihadist terrorism may be different, because unlike previous waves in the modern era, this wave was driven by religious reasons. Therefore, many researchers are reluctant to predict the end. ${ }^{4}$

\subsection{Theoretical and Conceptual Framework}

\section{Terrorist Group Dynamics}

The approach that is particularly popular among terrorism experts is analyzing the organizational dynamics of terrorist groups. Research has concluded that terrorism is basically a group activity. By understanding group dynamics, including ideological commitment and group identity, researchers can see ways to end terrorist groups and terrorist attacks. Thus, the focus is on the dynamics of relationships between members as a way to gain insight into the vulnerability of group hierarchies, weaknesses in their organizational structures, group ideology, and world views, and so on. This, in turn, has the potential to explain how a group can be decomposed. Such research analyses the behavior of terrorist groups from the perspective of the needs of the organization itself, an approach that is particularly influential in studying the behavior of leftist and ethnic nationalist or separatist groups in the 1970 s and 1980s. ${ }^{5}$

However, many question the relevance of this established approach in the era of decentralized non-hierarchical cell structures that can exploit information technology and the tools of globalization. The internet emerged as a critical new dimension of 20th-century global terrorism, with websites spreading ideological messages, perpetuating terrorist networks, providing links between operators in cyberspace, and sharing images of violence to show cruelty and incite followers to Act. Likewise, more emphasis is placed on individual initiatives. It is thought that 90 percent of terrorist organizations have a life span of less than one year; and of those who reach one year, more than half disappear in a decade. Whether an organization supports left-wing, right-wing or separatist reasons seems necessary in determining its life span. Of the three, terrorist groups motivated by ethnic nationalist or separatist reasons have the longest average life span; their greater average longevity seems to result, at least in part, from support among residents of the same ethnic group for the group's political or territorial purposes.

However, this view may be too hasty to see the average life span of contemporary terrorist groups motivated by religion, or at least groups that draw on the concept of religion as a driving force. The extraordinary resilience of religious terrorist groups seems to indicate the inherent

\footnotetext{
${ }^{3}$ Audrey Kurth Cronin, “How al-Qaida Ends,” International Security, Vol. 31, No. 1, 2006.

${ }^{4}$ Ibid.

${ }^{5}$ Ibid.
} 
strength of motivation that is sacred or religious based. ${ }^{6}$ The JAD case proves this research which shows how the 'ideology' of ISIS despite being crushed by coalition forces in the Middle East, but remains an attraction for radical groups in other countries which in this case greatly influences JAD.

\section{Social Movement}

Other researchers study the evolution of terrorist groups as a type of social movement. A broad collection of individual and organizational actors unified by historical moments, critical cultural experiences, and communication flows are social movement. A sense of solidarity or unity enables the articulation and realization of profound (even revolutionary) changes in societies and across them are crucial. ${ }^{7}$ The more developed literature on social movements presupposes, for example, that terrorism can emerge at the end of the cycle of rising and fall of mass movements. Social movements easily drawn towards more positive means. Understanding the patterns of mobilization may be necessary for dissecting the origins of established groups, but may not reveal the possible end. Overall, research on social movements provides more insight into terrorist groups than having to enter into extraordinary lines.

The JAD organization has a conventional structure like a terrorist organization in general, although it is arguably less neat. At the provincial or regional level led by an amir, then at the district level is mudiriyah, and finally is qoryah or sub-district level. It is not yet known whether JAD has a da'wah wing for recruitment and management to the smallest units such as Jemaah Islamiyah (JI). In contrast to JI, JAD amirs in the regions can freely launch terror attacks without having to report and coordinate with the central amir. Central Java's JAD, led by Fauzan Mubarok, is known to be planning to attack the police headquarters in Tuban, East Java. In Bima, NTB, a member of JAD led by Abu Salma in September 2017 shot a police officer who caused injuries. All of these attacks took place independently without being noticed by JAD officials at the center.

The organizational structure of JAD is known to exist in several provinces such as West Java, Central Java, East Java, Kalimantan, South Sulawesi, Ambon, West Nusa Tenggara, and Jabodetabek. The exact number of followers so far has not been detected yet. Now most of the key figures in JAD have been captured by Detachment 88 . But there are still many who have yet to be found. Although some JAD officials have been arrested, it does not mean that the threat of attack will just disappear. We know that JAD is the largest ISIS support group, but it is not alone. Aman, as a religious leader, is not included in the organizational structure. In a terrorism network in Indonesia, religious leaders are sometimes not included in the organizational hierarchy. Religious leaders, sometimes also do not know the details of the organization's operational activities.

\section{Terrorism as Network}

Terrorist groups often access and deploy critical resources, such as people, finances, and information while overcoming the hurdles of contested environments. ${ }^{8}$ Moreover, transaction or coordination costs drop dramatically with networked technologies, like computer networks or mobile telephones that amplify and accelerate the reach, resilience, and value of networks. Terrorism can be organized as networks of formal organizations, institutions, and other

\footnotetext{
${ }^{6}$ Ibid.

7 J. Comas, P. Shrivastava \& E.C. Martin, "Terrorism as Formal Organization, Network, and Social Movement, " Journal of Management Inquiry, 24 (1), 2015.

${ }^{8}$ Ibid.
} 
organized elements that work to achieve multiple and sometimes conflicting goals. ${ }^{9}$ Terror groups often exhibit some characteristics of networks but seem to have elements of "clan" or kinship groups bound by ideology and culture as well. ${ }^{10}$

Joose stated that many scholars have pointed to leaderless modes of mobilization being a hallmark of the "new terrorism" network. ${ }^{11}$ This perspective maintains a focus on the globalization of social movements, internet-based radicalization, and the importance of social media for communication and coordination. Leaderless emerged as a doctrine in the radical right, ideologies of leaderless, incorporating assertions about the similarity, capability, and effervescent nature of the actors involved, are prone to be developed in many different contexts of asymmetrical conflict.

Seeing the cases of terrorism in 2010-2018, what happened were many individual acts of terrorism or lone wolf terrorism. Spaaij formulated the characteristics of Lone Wolf Terrorism, among others: (1) carried out individually; (2) is not part of a terrorist group or network; (3) the modus operandi is understood and regulated by individuals without command. These three characteristics are very different from terrorism which is controlled through organizations consisting of many members, a giant network and supported by means and implemented in a planned manner. ${ }^{12}$

\section{End of Terrorist Groups Variables}

The decline and end of terrorist groups in the modern era are had seven broad explanations: (1) capturing or killing leaders, (2) failure to transition to the next generation, (3) achieving group goals, (4) negotiations towards a transition to a legitimate political process, (5) how to support the community, (6) military force and repression of terrorist groups. (7) the transition from terrorism to other forms of violence. Relevant factors can be internal and external: terrorist groups explode for reasons that may or may not be related to actions taken against them. They also do not have to be separate and different. ${ }^{13}$

In several studies, it has been shown that the arrest or killing of a leader of a terrorist organization proves to be a necessary element in organizational decline. From a counterterrorism perspective, the killing of a terrorist leader can be supported by creating increased publicity for the group's goals and possibly making the leader a martyr who will attract new members to the next organization or even the organization. Che Guevera is the most famous example of this phenomenon. ${ }^{14}$

The other variable is the failure to transition to the next generation. Some terrorist organizations cease to exist after they fulfill their original purpose. In the context of 20th-century terrorism, additional categories are possible. Although it occurs in a small number of cases, using terrorism to achieve a goal is sometimes successful. ${ }^{15}$ The concept of failure to transition to the next generation is closely related to the theory which states that terrorist violence is associated with the ups and downs of generations. The ideological nature of groups seems relevant to the durability across generations of terrorist groups. The internal processes that occur

\footnotetext{
${ }^{9}$ Ibid.

${ }^{10}$ Ibid.

${ }^{11}$ Paul Joosee, "Leaderless Resistance and the Loneliness of Lone Wolves: Exploring the Rhetorical Dynamics of

Lone Actor Violence," Terrorism and Political Violence, 29:1, 2017.

${ }^{12}$ R. F. J. Spaaij, Understanding Lone Wolf Terrorism, (Dordrecht: Springer, 2012).

${ }^{13}$ Cronin, Loc. Cit.

${ }^{14}$ Ibid.

${ }^{15}$ Ibid.
} 
during the transition from the first generation terrorist leader to the second generation are susceptible. The failure to pass down a legacy to a new generation is a general historical explanation for the decline or end of terrorist groups. ${ }^{16}$

Another variable is achieving group goals and negotiation. The opening of negotiations can be a catalyst for the decline or end of terrorist groups, which has the potential to influence negative impacts. Groups must be transformed into political legitimacy and away from terrorist behavior after the official opening of the political process. However, typical scenarios for the decline of terrorist groups are usually far more complicated than just pursuing or achieving negotiated agreements.

Apart from the successful outcome of negotiations that can be produced between significant parties, the general effect of the political process is the splitting of groups into factions that support negotiations and those that do not. Breaking up groups can be the goal of the negotiation process because it isolates and potentially strangles the most radical factions. Indeed, most researchers assume that negotiations will never lead to the end of a terrorist group. This applies to almost all terrorist groups including JAD groups. Because, almost all terrorist groups have apocalyptic demands that cannot be negotiated. ${ }^{17}$

Negotiations able to complicate terrorist efforts as an effort to maintain a legitimate political perspective in justifying the use of terrorist violence. A form of negotiation with terrorist organizations, or more precisely with its members, is an offer of amnesty for those who want to stop engaging in violence and want to provide supporting information. When an organization faces defeat and its members have an incentive to find a way out of what they see as the cause of defeat, amnesty are the most successful tools. ${ }^{18}$

There are more than one dynamic responsible for the decline of terrorist groups. Government underestimates the ability and dynamics of the group itself and is often misdirected; even among groups who refuse to respond to counter-terrorism campaigns, the picture remains complex. Anti-terrorism techniques are often best used in combination, and methods can overlap: often more than one technique is used to respond to specific groups at different times. The aim here is to focus on the historical experience of previous groups and study the similarities, both in internal and external variables, to determine aspects of the process of terrorist reduction that are relevant to terrorist groups.

The other variable is support from the community. Terrorist groups are strategic actors who usually consider their targets and calculate the impact of attacks on the population of their constituents. However, incorrect calculations can damage the cause of a group, resulting in dropin community support and even its destruction. Terrorist groups generally cannot survive without active or passive support from the surrounding community. For example, citizens support by hiding members of terrorist groups, collecting money, and even participating terrorist organizations. Passive support, more widespread and includes actions such as ignoring tangible signs of terrorist group activities, refusing to cooperate with police investigations, sending money to organizations that act as a front for the group, and express support for the group's goals.

Public support for terrorist groups can disappear for several reasons. First, people who are not too interested in political objectives may be afraid of the government's reaction. Apathy is a very strong force; all the same, most people naturally prefer to live their daily lives without the threat of being targeted by counterterrorism laws, regulations, sanctions, and raids. Sometimes

${ }^{16} \mathrm{Ibid}$.
${ }^{17} \mathrm{Ibid}$.
${ }^{18} \mathrm{Ibid}$. 
even highly radicalized societies can withdraw active or passive support for groups, especially if the government takes punitive measures.

Second, the reform movement increased spending, and job creation in underserved areas are tactics that can undermine the sources of terrorist violence. Evidence shows that the extent to which community conditions lead to feelings of "anger" or frustration ambition among specific segments of society during the transition period may be an necessary factor for the decision to turn to terrorist violence.

Third, people can become uninterested in the ideology or goals of terrorist groups; events can develop independently so the objectives of terrorist groups become obsolete or irrelevant. A sense of maturity or opportunity might have been lost. This could be the main reason why the nature of transnational terrorism networks has developed beyond the main dependence on state sponsors for broader criminal or entrepreneurial behavior. Fourth, terrorist groups' attacks cause disgust toward potential supporters or groups. ${ }^{19}$

Another variable is used by military forces. The use of military force has accelerated the decline or ended several terrorist groups. From the perspective of the state, military power offers the means available under its control. Although terrorism is arguably a form of war, terrorists use asymmetrical violence. In some circumstances, this works. Historically, military power has taken two forms: intervention, when the threat mainly lies outside the borders of target countries such as Israel's involvement in 1982 in Lebanon; or oppression, when threats are considered primarily domestic threats as is the case with the PKK. More specifically, the state will use a combination of both as in Colombia. ${ }^{20}$ Democracy or liberal governments face particular difficulties in suppressing terrorist groups. Because military or police actions require targets, the use of force against operators works best in situations where members of the organization can be separated from the general public. ${ }^{21}$

And the last one is the transition from terrorism to other forms of violence. In some cases, groups terrorism can change to classical criminal behavior or conventional warfare with a change from the main emphasis on pooling resources as a means of achieving political goals towards obtaining material and profitable goals within themselves. Groups that have made such a transition in recent years include Abu Sayyaf in the Philippines and are arguable all the significant groups called terrorist-narcotics groups in Colombia. Beginning in 2000, the Abu Sayyaf changed its focus from targeted bombings and executions to hostage-taking of foreign hostages and their exchange for millions of dollars in ransom..$^{22}$

\section{Research Methods}

The method used is descriptive-analytical, to describe a phenomenon to learn the aspects of who, what, when, and how of a topic. For the Faded, descriptive research will give a description, description or condition as clear as possible without any particular treatment of the object being researched.23 The type of study used is case studies following the opinion of Yin,

\footnotetext{
${ }^{19} \mathrm{Ibid}$.

${ }^{20}$ Ibid.

${ }^{21}$ Ibid.

${ }^{22}$ Ibid.

${ }^{23}$ Robert K. Yin, "Case Study Research Design and Methods", dalam M.Djuazi Mudzakir, eds., Studi Kasus

Desain \& Metode, (Jakarta: PT. Raja Grafindo Persada, 2005).
} 
that case studies do not require complete or accurate translation of actual events, as directed at the development of frameworks in understand the complex social phenomena to maintain the characteristics of organizational cycles, social change, and international relations. ${ }^{24}$

\section{Discussion}

The seven variables which can forecast the terrorist group can be used as analysis tools to forecast the end of JAD in Indonesia. The variable is 1) Arrest or kill the leader of a terrorist group. Killing a terrorist leader vary greatly depending on variables such as organizational structure, whether the leader creates a cult of personality and the presence of a worthy successor. There are several reasons t that capturing a leader is more effective in damaging a group than killing him. But even shameful arrests can support if imprisoned leaders continue to communicate with their groups.

Aman Abdurrahman as an necessary figure or so-called 'ideologist' in the JAD circle was convicted of the Cimanggis bombing case and subsequently successive terror cases in the Thamrin Bomb case, etc. Through his 'fatwa' in prison, Aman Abdurrahman is seen to influence the actions of JAD personnel who carry out independently. Many of Aman Abdurrahman was able to indoctrinate terrorists in prison while in prison so that they were increasingly militant and ready to carry out acts of terror. This fact proves that in other cases, the leaders of terror groups such as Aman Abdurrahman from JAD who were imprisoned could encourage further violence by group members who tried to free them. However, if a leader is arrested and imprisoned, destroys his credibility and interrupts communication, this is very necessary to reduce the morale of his followers. ${ }^{25}$

Once Aman Abdurrahman is executed a successor will reappear. The JAD group is also likely to change the mode of attack to be carried out. Chances are they will practice harder. For example involving families, children, women, and people who have not been suspected of being soldiers. The death sentence for Aman does not necessarily end terrorism. Nevertheless, Aman's death sentence is predicted to silence the JAD group. The reason, many JAD leaders such as M. Iqbal (JAD Jabar), as well as Zainal Arifin Ansori who incidentally the main Amir are languishing in prison. JAD will still exist even if the leader is sentenced to death. However, it did not rule out the possibility that JAD would break up because JAD officials, such as Khalid Abu Bakar, might leave the organization after Aman died. Besides, strong monitoring of the authorities and limited resources will make JAD temporarily inactive. So, in the short term, JAD will get down, and not form a structure like before it was open.

The other variable is 2) Achievement of group goals. The JAD group is a terrorist network based on extreme religious understanding. This group is takfiri and wants to establish a khilafah which is seen as the main goal of their struggle. Born in the form of a network after the birth of ISIS as if at the beginning of its emergence gave a new spirit to radical groups. They made acts of terror to achieve their goals. denied that the organization intended to carry out acts of terror. Despite their rebuttal or 'camouflage' their goal by declaring JAD only an organization that accommodates the spirit of jihad. The main objective of JAD is to facilitate the brothers, to support the Syiah movement.

\footnotetext{
${ }^{24}$ Ibid.

${ }^{25}$ Cronin, Loc. Cit.
} 
JAD uses acts of terror as the path they believe is 'legitimate' to achieve their goals. Looking at this perspective, the objectives that JAD intends to achieve have not yet been fulfilled, even though their militancy has not slowed down. JAD is not like a separatist-based terrorist group that can sit together with the government after their goals are seen successful. This is where $\mathrm{JAD}$ is still difficult to compromise because the purpose of the Khilafah that they are carrying is contrary to the ideology of the Republic of Indonesia.

Therefore, this variable still needs time to make a compromise with JAD for reconciliation for example. Even though the goals or ideals carried by JAD have not been achieved or indeed they are utopian ideals, but with restrictions through law and raising people to refuse, the existence of JAD will decline. With the category of a prohibited organization that has been legally endorsed by the state, the steps to achieve the objectives of JAD are closed or locked dead. And this is a step to gradually see the decline and even death of JAD in Indonesia.

The other variable is 3 ) Negotiations leading to a transition to a legitimate political process. The Indonesian government may face great difficulties when negotiating with terrorist organizations such as JAD. In JAD itself, it might be divided when there is a kind of negotiation, some reject and support. Splinter groups when they occur within JAD can often be crueler than "mother" organizations, responding to the necessity to show their existence and give a sign of their dissent. Splinter groups can be seen as involved in a new "layer" of terrorism in connection with indigenous groups or their governments.

Various variables can determine the outcome of broader negotiations to end terrorism, including the nature of group organizations (with hierarchical groups having an advantage over groups that cannot control the actions of their members), the nature of group leadership (where groups with strong leaders have advantages over decentralized), and the nature of public support for this purpose where groups with ambivalent constituencies may compromise. Determining the extent to which open political dialogue with terrorist groups is likely to be a pathway to group decline and a reduction in violence is a very different calculation. Negotiation, however, does not need to be a formal process.

The offer of amnesty for JAD members can be an effective 'negotiation' effort. But is it possible for JAD who understands takfiri, this is still a separate question? JAD understands that it rejects democracy or a system of government that is deemed incompatible with the Shari'a. They refused the respect of the red and white flag and also refused the parole (PB) for the military among those who wished to be released. Therefore, this amnesty offer is like a maximum. Although in the ongoing process of seeing the dynamics of 'fluid' from JAD, this offer could be the final step for negotiations and reconciliation as fellow children of the nation. The amnesty step is indeed more humane. Do not rule out the possibility as a strategic step to 'turn off' the JAD network, the effectiveness of the amnesty offer as necessary step.

The other variable is 4) Inability to forwarding to the Next Generation. JAD emerged at the initiative of Aman Abdurrahman. This figure has received a death sentence is indeed a great reference for sympathizers and supporters of JAD. Although to Aman Abdurrahman, there are still amirs in the body of JAD who act as 'ideologists' to move the action. For example, Khalid Abu Bakr, who until now has not been captured. Khalid's figure represented a real threat in terms of the ideology of a terror group network that understood the Khilafah. Although Khalid operationally did not order a direct attack, the inspiration and teachings propagated by Khalid proved to be a fuel capable of moving terror cells.

The body of JAD, related to regeneration can see how JAD cells move independently and without a single leadership authorization. Members who participate small cells in each area may not know each other, making the tracking process difficult for the police. To map their networks would specifically be more difficult when compared to terror eradication operations in the JI 
era. JAD small cells can move independently without having to wait for the command. These cells are dangerous. One attack somewhere can inspire cells in another place, giving rise to a domino effect. This can indeed be a fact that regeneration to replace leaders who are captured or killed can be easily done. Aman Abdurrahman is known to have hundreds of followers and supporters who can be appointed at any time as leaders or members. There is always regeneration in terrorism networks.

However, regeneration in the terrorism network cannot be ignored. The appearance of a 'leader' in a terrorism network means that there is always a continuous regulation. In the JAD case, even though it is cell-based, in the absence of a leadership figure deemed qualified in a religious field such as Aman Abdurrahman, it can be a blow to the sustainability of the JAD network. And this can slowly reduce the militancy of followers so that the network stops. In the future predictions after Aman Abdurrahman through the regeneration variable, seems to be no figure that is considered qualified and authoritative among JAD followers. And this will reduce the dynamics of the JAD network following waning JAD actions.

The other variable is 5) Decreased community support. In the case of JAD in Indonesia, the significant of the population, especially those in the moderate category, did not support much. This process is 'natural' where the power that promotes violence in Indonesia will not generate much sympathy. Those who sympathize are mostly those who have 'fallen' into radical movements and terrorism. This makes it easy for those categories who can enter the JAD circle. Because JAD also does not 'organize' in its actions and is more lone wolf realized, here it is indeed difficult to detect this JAD support group.

Among the jihadists themselves is divided understanding of amaliyat. Many of them think violence in realizing struggle is no longer effective. They reject ISIS views and actions. Many of them consider that ISIS (JAD) is an excessive jihadist group (ghuluw) or khawarij which in Islamic history is a splinter group that was abandoned by many Muslims at that time. This means that the teachings of excessive violence are prohibited in Islamic teachings. They then prefer the missionary path by establishing taklim-taklim. There are actually a few groups like JAD who understand ISIS. With this divisive view among jihadists, it has the potential to further reduce support for JAD. With fact that the community's isolation of JAD and strengthened mobilization measures to undermine JAD supporters, will make JAD decrease its strength. And this will be an effective trigger process for his death.

The other variable is 6) Military power and repression against terrorist groups. Repressive actions can also take the form of legal aspects. In the JAD case, there was already a legal ruling to ban it. The court has determined that JAD commits a criminal act of terrorism because the organization initiated by convicted Aman Abdurrahman often commits terror. For this reason, there is a ban on JAD organizations operating in Indonesia. JAD is considered to have violated article 17 paragraph 1 and paragraph 2 jo article 6 law Number 1 of 2002 concerning the eradication of criminal acts of terrorism as has been determined to be Law Number 15 of 2003 or article 17 paragraph 1 and paragraph 2 jo of article 7 law Number 1 of 2002 concerning eradicating criminal acts of terrorism as stipulated in Law Number 15 of 2003. With this indictment, the public is prohibited from participating JAD. If proven to participate, then that person can be subject to criminal penalties.

The verdict of the panel of judges could be the basis for arresting JAD members or sympathizers who might be still hanging around. The assumption is that someone proven to be affiliated with JAD can be subject to multiple articles; participate banned organizations and spread terror. Even though JAD is not the only terrorist organization in Indonesia. Because there are still small factions that may not be connected to JAD. Repressive actions do carry high resource and opportunity costs. These long-term punitive measures against JAD terrorism 
suspects can reduce domestic support and filter the country's order. Furthermore, punitive actions can reduce JAD's ability to respond effectively to terrorist attacks in the future.

The other variable is 7) Transition to another modus operandi. JAD as a terrorist group can indeed do anything to realize its ideals of jihad. In other words, it justifies any means. And this is evidenced by many other terrorist groups such as the Abu Sayyaf who have accompanied terrorist acts with robberies and kidnappings. In JAD's view, for example - and this also exists in the thinking of other terrorist groups in Indonesia - such as the concept of 'fa' $i$ 'has been used as a tool to justify the means for funding terrorist acts. Funding through this concept has been proven to occur in Indonesia since Imam Samudra robbed a gold shop in Serang and also a case of a CIMB bank robbery in Medan. Besides to murder, bombing or other acts of violence that are lawful by JAD against those who are seen as infidels or thaghut, robbery is very likely to occur with the arguments of the Shari'a. Nevertheless, to turn into a criminal group, JAD spesificly still weighs. The reason is that JAD relies on the ideals of the Shari'a which they believe are for the establishment of the Islamic Caliphate or Sharia in total. Jad only made crime as part of their view of the Shari'a. They only seek the legitimacy of their Shari'a, and do not substitute their group for example as a criminal gang. Terrorism and crime are not the same, but they are related. Movements like JAD have proven to justify any means. And funding action can be done by criminal means.

\section{Conclusion and Recommendation}

The extreme group Jamaah Ansharut Daulah (JAD) may have been paralyzed after a judicial verdict in 2018. Although in fact after the Kampung Melayu bomb attack that killed five people including three members of the police, JAD's whereabouts had faltered. Dozens of necessary JAD members have been detained while others have died. At a glance, JAD seems to have died, but it is believed that the group has the potential to launch terror attacks.

It's no exaggeration to say that JAD needs particular attention. The group that emerged from the splinter of the Islamic State of Indonesia (NII), despite not having a capable military capability, proved capable of spreading terror in various regions. Its members are spread throughout almost all of Indonesia. JAD which emerged shortly after ISIS declared its caliphate in Syria and Iraq on June 29, 2014, became its challenge in the counterterrorism framework in Indonesia.

From the 7 variables described above, it can be used as forecasting of setbacks, decreases and even deaths of JAD in Indonesia. At least the decline as a keyword for research on the dynamics of the JAD network and the actions that can be predicted. From these variables, the court's verdict on JAD's prohibition becomes a legitimate 'milestone' to undermine JAD's acceleration. This stipulation becomes an necessary foundation to block the pace of JAD movement in Indonesia. Although not all of the seven variables can be used as binocular tools to predict the death of JAD, at least the existing variables are already relevant to see the decline or decrease in the dynamics of JAD.

From the reading of various views of the results of the study indeed almost all stated that JAD was difficult to die. This is because of the JAD movement which is 'unusual' in the sense of not having an organization like other terrorist groups such as Jemaah Islamiyah (JI). With cell systems and lone-wolf attacks and the power of takfiro ideology held by JAD, like other terrorist groups, it becomes an 'obstacle' to kill JAD. Likewise, the matter of regeneration is still open to JAD even though the main leader or his ideology has been sentenced to death. In a circle 
of terrorist wounds, regeneration will grow continuously. People who support terrorism do not always need an organization with a rigid structure. In a sense, they can move independently without having to take part in tasks within the organization. Terrorist groups feel more united by one ideology than united by an organization. JAD supporters from the start did not care about the organization, they could move without an organization.

Therefore also, a strong counterterrorism policy must be based on various historical lessons learned about which policies succeed, and under what conditions, to accelerate the decline and death of terrorism. Treating JAD as if sui generis is an inaccuracy. Although there are unique aspects of threats that are suddenly carried out by JAD, there are also connections to previous threats. Talking about the unprecedented threat of "jihadists", while arguably resonating in a domestic context, only perpetuates the misguided image and romanticism of the JAD movement, making its ideology more attractive to recruited candidates.

Terrorism, like war, never ends. Because there are always individual terrorist campaigns and groups that always do it. The declaration made by the government on the war on terrorism has brought a vague concept of the ending phase of JAD rather than a convincing road map for how it will be reduced to a small threat level. The threat of JAD is real and cannot be denied. Efforts to continue the ahistorical approach to encourage JAD's death are still a long process. Therefore, effective steps are needed, not to waste power.

\section{References}

[1] Comas, J., Shrivastava, P., \& Martin, E. C.: Terrorism as Formal Organization, Network, and Social Movement.

Journal of Management Inquiry, 24(1), 47-60.doi:10.1177/1056492614538486 (2015)

[2] Cronin, Audrey Kurth.: How al-Qaida Ends. International Security, Vol. 31, No. 1, by the President and Fellows

of Harvard College and the Massachusetts Institute of Technology (2006)

[3] Joosse, Paul: Leaderless Resistance and the Loneliness of Lone Wolves: Exploring the Rhetorical Dynamics of

Lone Actor Violence, Terrorism and Political Violence, 29:1, 52-78, DOI: 10.1080/09546553.2014.987866

(2017)

[4] Moghadam, Assaf: Failure and Disengagement in the Red ArmyFaction. International Institute for Counter-

Terrorism (ICT), Lauder School of Government, Diplomacy and Strategy, Interdisciplinary Center (IDC) Herzliya, Herzliya, Israel Published online: (2012)

[5] Rapoport, David C: The Four Waves of Rebel Terror and September 11. Anthropoetics 8, no. 1, Spring / Summer (2002)

[6] Spaaij, R. F. J: Understanding Lone Wolf Terrorism. Dordrecht: Springer (2012)

[7] Turner, Carl Peter: How terrorism ends: a comparative conflict analysis of Northern Ireland, the Basque Country,

and Corsica. Thesis Ph.D. https://ethos.bl.uk/OrderDetails.do?uin=uk.bl.ethos.693803 (2015)

[8] Yin, K Robert: "Case Study Research Design and Methods", dalam M.Djuazi Mudzakir, eds., Studi Kasus

Desain \& Metode, PT. Raja Grafindo Persada, Jakarta (2005)

[9] Zulaika, Joseba., \& Murua, Imanol: How terrorism ends - and does not end: the Basque case, Critical Studies on Terrorism, 10:2, 338-356. (2017) 